\title{
Energy Efficiency as an Indicator of Sustainable Development Policy: The Azerbaijan Experience
}

\author{
Urkhan Alakbarov $^{1} \&$ John E. S. Lawrence ${ }^{2}$ \\ ${ }^{1}$ The Academy of Public Administration under the President of the Azerbaijan Republic, Baku, Azerbaijan \\ ${ }^{2}$ School of International and Public Affairs, Columbia University, New York, USA \\ Correspondence: Urkhan Alakbarov, The Academy of Public Administration under the President of the \\ Azerbaijan Republic, Baku, Azerbaijan. E-mail: alakbarovuk@gmail.com
}

\author{
Received: March 23, $2017 \quad$ Accepted: May 2, $2017 \quad$ Online Published: May 31, 2017 \\ doi:10.5539/jsd.v10n3p187 URL: https://doi.org/10.5539/jsd.v10n3p187
}

\begin{abstract}
In face of mounting evidence for complex environmental threats to human development, countries have been seeking new paths to progress less damaging to the planet. The objective of this paper is to explore innovative ways for monitoring efficiency of sustainable development policy, not only in the Caucasus region, but beyond. We propose that this goal can beachieved through two steps: measuring energy use as a contributing element to gross domestic production (GDP) and the associated progression in equitable distribution of national wealth. The case is presented of Azerbaijan, a vibrant, resource-rich Caucasian country which has demonstrated spectacular GDP growth only a few years into independence from the former Soviet Union. Using a single indicator, energy consumption for GDP production, in association with the classic Gini coefficient of economic equity, the authors argue empirically for renewed and innovative measurement of progress towards achievement of crucial United Nations Sustainable Development Goals.
\end{abstract}

Keywords: sustainable development, public administration, energy efficiency, human development, social policy

\section{Introduction}

The $70^{\text {th }}$ jubilee session of the UN General Assembly (2015) took place in September in New York. The Assembly discussed major challenges facing humanity in the $21^{\text {st }}$ century, and identified immediate and longer term measures to overcome them. It was acknowledged that a new approach to development -intended to ensure the well-being of present generations and at the same time create the conditions for progress for future generations - is a key priority for the $21^{\text {st }}$ century, and the whole of the third millennium. The UN World Summit (2015), which took place in New York at the same time as the UN General Assembly session, simultaneously endorsed "sustainable development" as a key priority for our planet, and entered history as the Sustainable Development Summit.

Seventeen "Sustainable Development Goals" (SDGs, 2016) were adopted following the results of these global forums. Hundreds of underlying specific measures (indicators) were identified for the international community as whole, and for individual countries themselves. For the first time, all participating nations have agreed to implement measurable actions towards SDG achievement, in the 2015-2030 period, as a means for comparative assessment of progress. The goals address a wide spectrum of problems such as the eradication of poverty and inequality, natural resources management and environmental protection, as well as the formation and fostering of the necessary human potential and consequent intensive transfer of knowledge and technology (Costensa et al, 2016).

Effectively assessing SDG progress requires an entirely new vision of cooperation between government and civil society. This process is just starting, building on earlier experience with the Millennium Development Goals (MDGs), and an emerging, collective awareness of the seriousness of the challenge. At the center of competent and efficient SDG monitoring is a requirement for ensuring availability, accuracy and accessibility of data on each of the indicators that can calibrate activities in the desired direction of greater sustainability of operations in all sectors, especially public participation and trust in this entire process. Although the choice of indicators is an ongoing project, indicators, as currently specified, reflect the situation across different areas of sustainable 
development, and constitute a comprehensive set of economic, environmental and social performance measures (Dunning, 2016).

\section{Method and Country Selection}

The case discussed in this paper represents a singular application in an emerging country on the Asian and European border, and focuses on one single indicator to examine targeted attention, in the crucial area of energy (Goal \#7), to the kind of "express" monitoring so important to immediate, priority policy. We argue that because this same indicator can be presented when making international comparisons concerning Goal \#7, it is especially useful. It is also critical that this indicator is a part of regular statistical surveys and so does not require resources to carry out a special survey.

Our chosen indicator is energy consumption for the production of GDP, using data that are regularly published by multilateral agencies such as the UN, and World Bank. In calculating these figures, two methods are used based on international statistics: (1) gross domestic product (GDP) produced per unit of energy consumed and (2) energy spent for the production the GDP value of US $\$ 1,000$ taking into account purchasing power parity (PPP). Both these factors offer a useful composite measure of the effectiveness of sustainable development policies because: (a) lower energy consumption for the production of the same amount of GDP is important to an efficient economy, and (b) lower energy consumption also means less decrement at least of fossil fuel resources for future generations, and (c) lower energy consumption means reducing emissions of greenhouse gases into the atmosphere thus reducing impact on global climate change. Furthermore, a functionally efficient economy clearly facilitates favorable conditions for social sustainability.

The international methodology we employ here (World Bank 2017 a) takes as a unit of energy that which is contained in one kilogram of oil (there are about 136 kilograms in one barrel of oil). Energy can be obtained in different ways: by thermal, nuclear, and hydroelectric power plants, as well as by solar energy or any other renewable source. Our choice of the amount of units of energy, which is contained in one kilogram of crude oil, is premised on the fact that this measure creates an opportunity to compare energy efficiency in different countries across regions. In a given particular time frame the price of oil is the same everywhere.

The country we present for our case is the Azerbaijan Republic. This country has sought to restore its independency from the former Soviet Union, and has surprised the international community with its economic growth (World Bank, 2017 b), leading the world with spectacular GDP per capita acceleration approaching $30 \%$ annually during the last decade.

\section{Results}

The GDP per capita growth in Azerbaijan has been accompanied by extraordinary energy efficiency in national production processes in this country. An analysis of international statistics show that compared with 2003, in 2014 (the latest data published by the World Bank in February 2017) energy cost for production of GDP in Azerbaijan declined by a factor of around three times. According to the World Bank in 2001 for the production of US\$ 1,000 of GDP, Azerbaijan expended energy equivalent to that contained in $292.7 \mathrm{~kg}$ of oil. Currently as of February 21, 2017 in order to achieve the same economic effect, the Azerbaijan "consumed energy equivalent" is $89.9 \mathrm{~kg}$ oil, i.e. almost 3.2 times smaller. This is the best result among countries that were formerly part of the Soviet Union, including those who have become members of the EU today (Figure 1). 


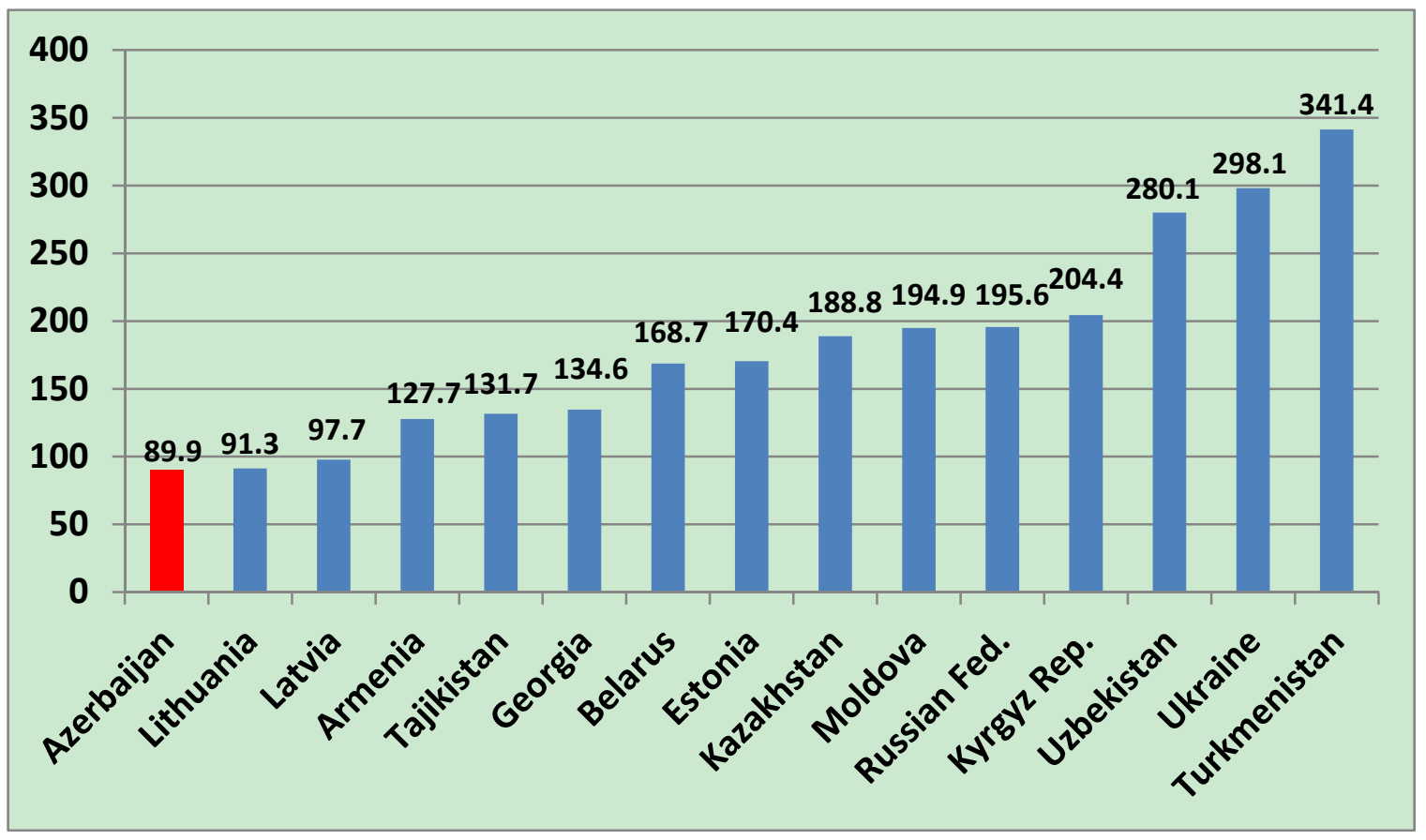

Figure 1. The post-Soviet countries: Energy (kg of oil equivalent) spent for 1,000 US\$ (PPP) GDP production (World Bank, 2017 a)

Azerbaijan achievements in this aspect of sustainable development can also be favorably compared to results achieved in the G7 countries. The same World Bank data (2017 a) show Azerbaijan to be, on this indicator, at 22 percent above the average of the G7, as well as better than many of other major economies such as Canada, USA, France and Japan (Figure 2).

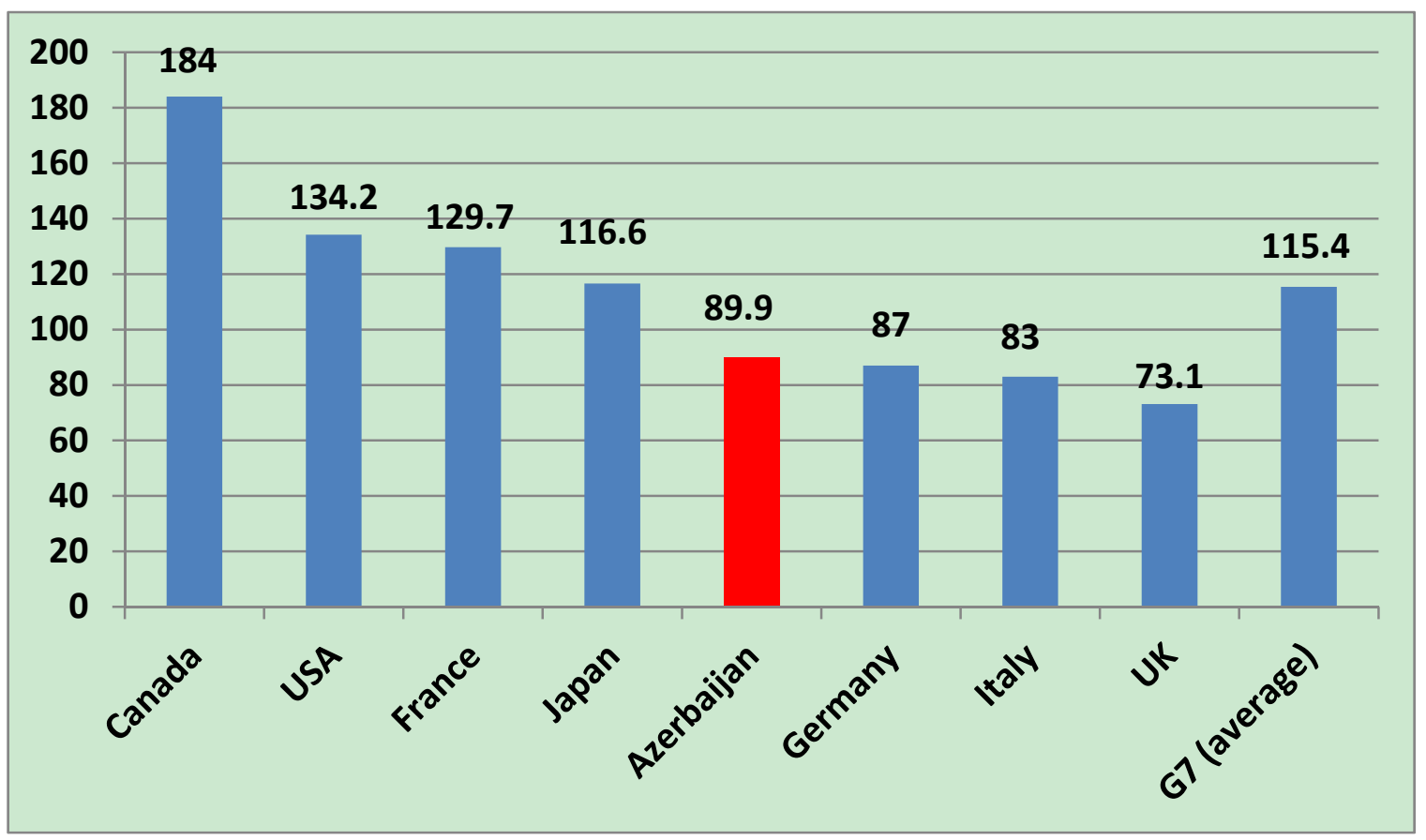

Figure 2. Energy (kg of oil equivalent) spent on the production of the GDP value of US\$ 1,000: G7 countries and the Azerbaijan Republic (World Bank, 2017 a) 
It could reasonably be assumed that such a rapid growth of sustainable development indicators in the Azerbaijan Republic may be based on the specifics of its economy, particularly the success of the extractive sector. If this is so, we can expect that similar trends should be observed in other countries exporting oil and gas. The results of this analysis are shown in Figure 3.

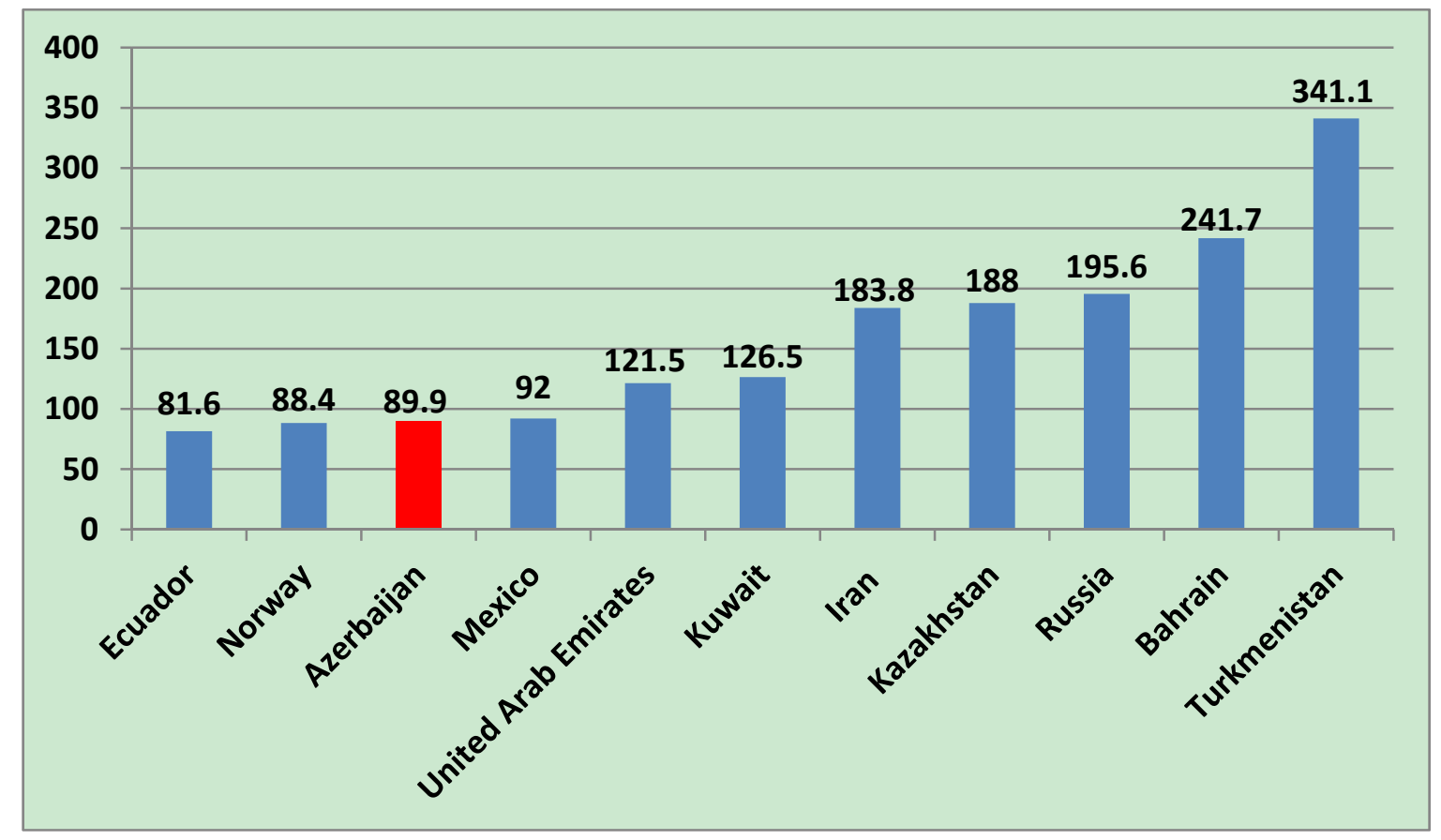

Figure 3. Energy (kg of oil equivalent) expended by oil and gas exporting countries for production US\$1,000 (PPP) GDP (World Bank, 2017 a)

These data describe the situation in countries belonging to the group of the Petroleum Exporting Countries (OPEC), as well as those that operate outside the framework of this organization. Comparative analysis shows that Azerbaijan is one of the leaders in this group of countries on this indicator.

The dramatic ascent of Azerbaijan on this indicator is a matter of record. According to the World Bank data in 2000 on this measure $(314.7 \mathrm{~kg}$ of oil equivalent for production US\$ 1,000 (PPP) GDP), Azerbaijan occupied one of the last places among countries-exporters of oil and gas, significantly behind Mexico, Kuwait, the United Arab Emirates, Iran, Kazakhstan, Bahrain and others. The nation however made significant progress over the last 15 years in this regard and has become now the one of the leaders of this group as shown in (Figure 3).

There are other data to support this conclusion. For example, the cost of energy expended in the production of the GDP value of 1,000 US\$ (PPP) in Azerbaijan is 32.8 US dollars. In Canada, the figure is 62.6, in Japan 36.1, 48 in Kuwait, and 79.9 in the Russian Federation. These results were obtained on the basis of World Bank data (World Bank 2017 a) and the cost of a barrel of oil at 50 US\$ as for September 1, 2016 year. These data suggest that this indicator can be used to assess the effectiveness of the planning and management of sustainable development.

Moreover, we argue that it is not only economic issues, but also factors related to the impact on global climate change and other environmental and social concerns that make Azerbaijan a particularly interesting subject for research. Its work is most instructive to the Caucasus region and beyond on developing strategic national development plans that take these complex policy priorities into consideration. The human potential based innovative development initiative, sparked by President Ilham Aliyev in a 2003 speech in Geneva (Aliyev, 2003), and referred to often since then (Aliyev, 2016), is one such example. Research supported by the UN Development Program examined comparative vulnerabilities to the Dutch disease across several economies, and made recommendations for broad, strategic and intersectoral options for Azerbaijan (Hopkins et. al., 2014; Lawrence 2015). In the quest for sustainable development, in accordance with international standards, successful progress is now seen as largely dependent on comprehensive and integrated socioeconomic policies. In Azerbaijan, there has been a notable emphasis on such policies directed at human resourcefulness as a result of 
good management of natural resource wealth (Alakbarov et. al., 2015).Following earlier research on these advances, it is here suggested that such progress can be quickly assessed, in broad terms, by consideration of a few specific indicators, among which the most common and widely used are the Gini Index and Quintile ratio.

The Gini index reflects the state of the distribution of income among the population. The index is counter-intuitive in that the lowest value indicates the most desirable (equitable) wealth distribution for a country. Figure 4 presents a comparative analysis of the Gini index in the G 7 countries and Azerbaijan Republic.

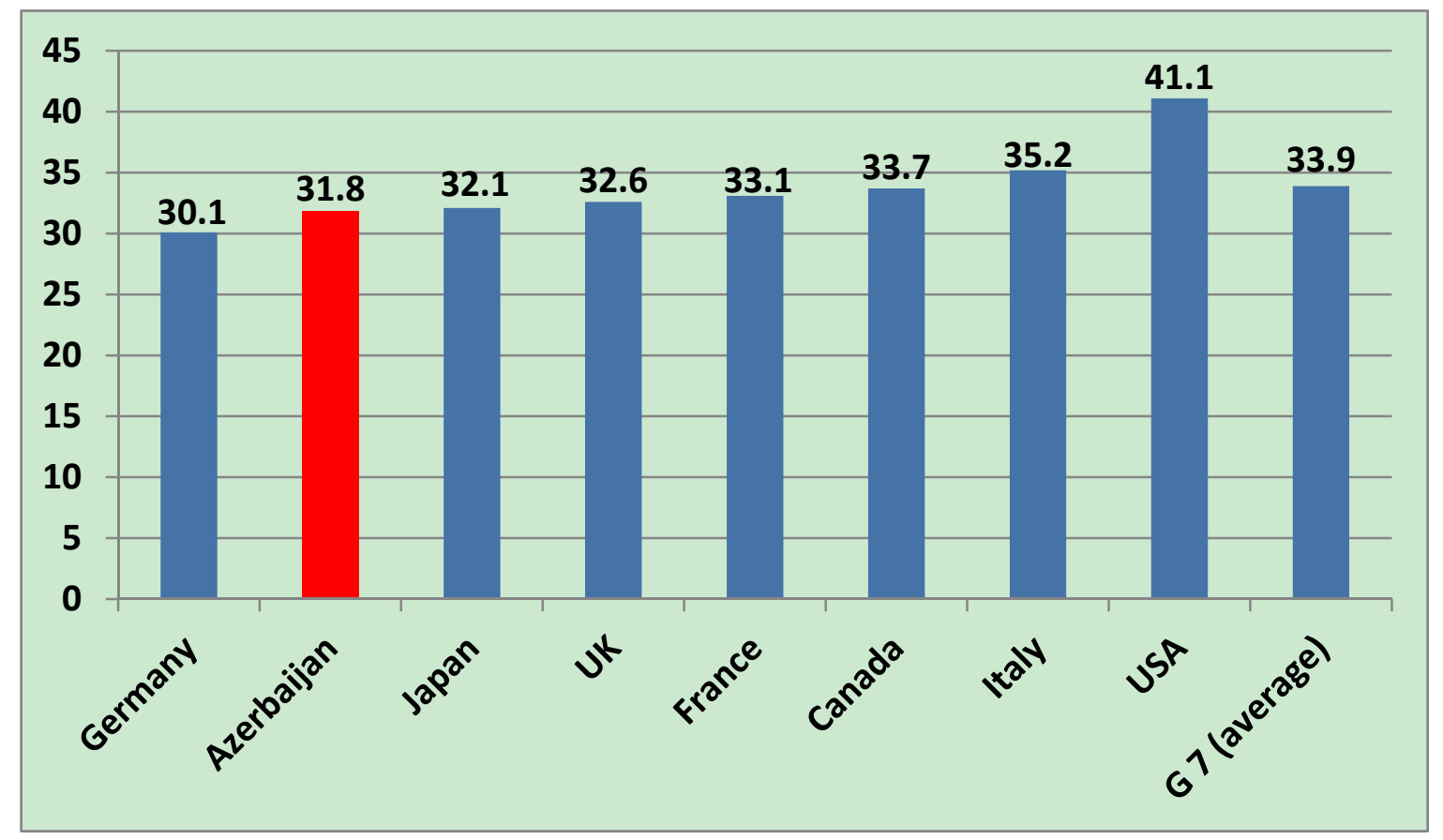

Figure 4. Analysis of social policy in the countries of G7 and Azerbaijan Republic: Gini index (HDR, 2016)

The data given in Figure 4 and based on UN official statistics, show that this index of social development in the Azerbaijan Republic is more favorable than the average in the countries of G7 and 6 countries - members of this organization.

The success of Azerbaijan's social policy is also supported by the results of Quintile ratio analysis (Figure 5). The Quintile indicator expresses the ratio of the average income of 20 percent of the population with highest income to the average income of 20 percent of the population with the lowest incomes. Low values of this index are considered as successful ongoing national social policy. 


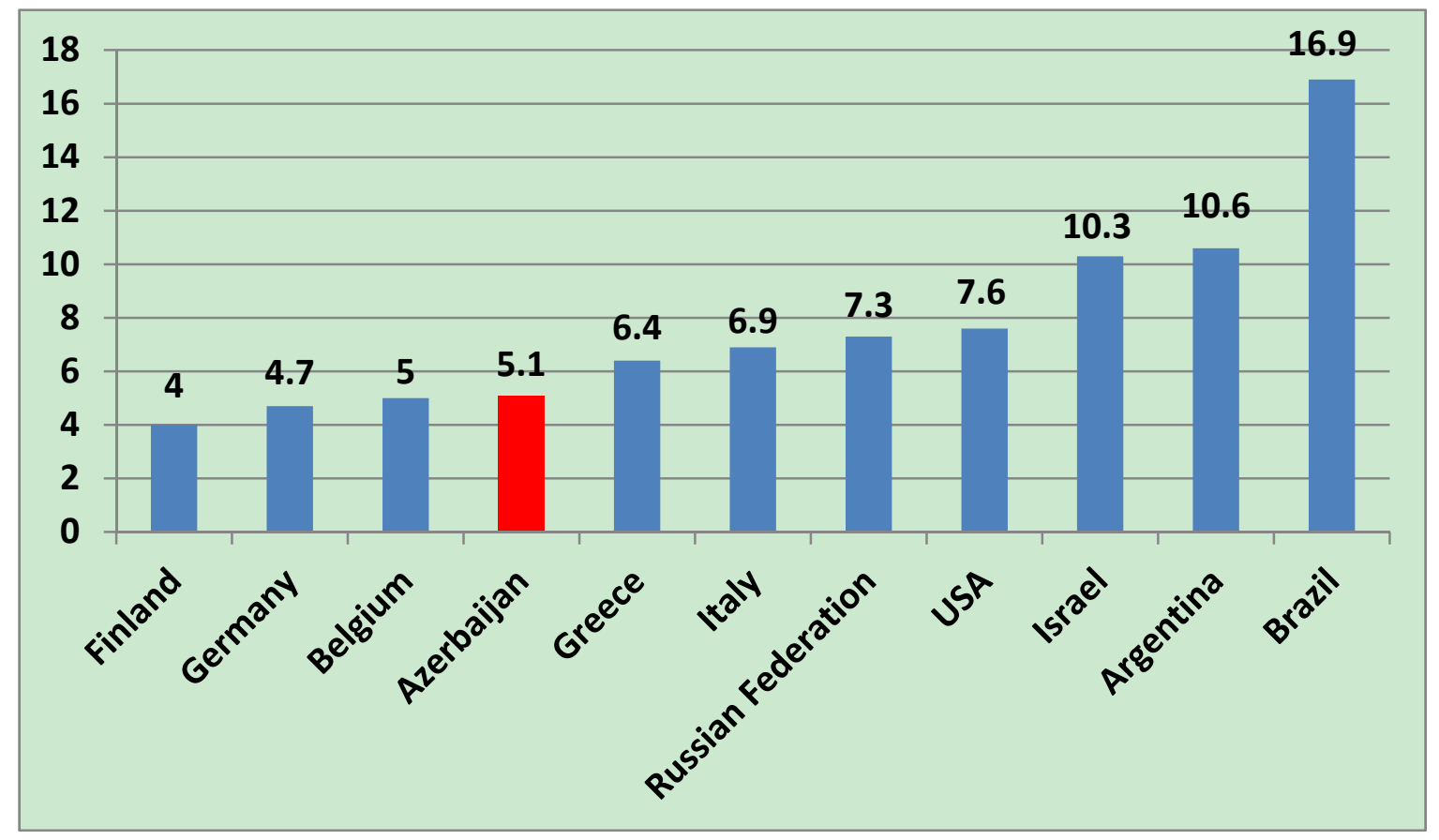

Figure 5. Analysis of social policy in the OECD countries and Azerbaijan Republic: Quintile ratio (HDR, 2014)

\section{Conclusions}

These data are presented by the authors as important and practically useful for policy purposes, and offer two conclusions: that energy efficiency in production can be a strategic indicator of sustainable development, and that in the case of Azerbaijan, this indicator is associated with favorable performance on other social indices, such as income distribution. We propose that these data also show how effective public administration and rational management of resources has dealt with the nation's development in unique ways, with attention to sustainability as a national priority. Azerbaijan's movement towards achievement of the SDGs and transition to ecological civilization (Alakbarov, 1998, 2013), is thus is on strong footing, and provides an interesting example to others.

\section{References}

Alakbarov, U. (1998). Ecologization of Human Activities. J. Energy, Ecology, Economy, 2, 141-143.

Alakbarov, U. (2013). Sustainable Human Development and Basic Ecological Civilization. Baku, Tehsil, p. 220.

Alakbarov, U., \& Lawrence, J.E.S. (2015).Towards Ecological Civilization: Ideas from Azerbaijan. Journal of Human Recourse and Sustainability Studies, 3, 93-10.http://dx.doi.org/10.4236/jhrss.2015.33013

Aliyev, I. (2003). Speech to World Summit on the Information Society, Geneva, Switzerland.

Aliyev, I. (2016).Speech to Baku Humanitarian Forum. Baku, Azerbaijan. Retrieved from http:/en.president.az/articles/21234/

Costanza, R., Floramonti,L., \&Kubiszewski, I. (2016). The UN Sustainable Development Goal and the Dynamics of Well-being. Frontiers in Ecology and the Environment. v. 12, 2, p. 59. Retrieved from https://researchers.anu.edu.au/publications/109954

Dunning, C. (2016). 230 Indicators Approved for SDG Agenda. Center for Global Development. Washington DC.Retrieved fromhttps://www.cgdev.org/blog/230-indicators-approved-sdg-agenda

Hopkins, M., \&Lawrence, J.E.S. (2014).Converting Black Gold into Human Gold. UN Development Program, Baku, fromhttp://www.az.undp.org/content/azerbaijan/en/home/library/human_development/blackgold_humangol d.html

Human Development Report. UNDP, New York, 2014. 
Human Development Report. UNDP, New York, 2016.

Lawrence, J.E.S. (2015). Black Gold to Human Gold: Natural and Human Resources Interface, the Case of Azerbaijan. In D. G.Nemeth, \&J.Kuriansky (Eds.),Ecopsychology: Advances from the Intersection of Psychology and Environmental Protection (Volume II. pp. 257-267). ABC-Clio/Praeger.

SDGs. (2016). Sustainable Development goals.Retrieved from www.un.org/sustainabledevelopment/sustainable-development-goals

UN 70 ${ }^{\text {th }}$ General Assembly. (2015). Retrieved from www.un.org/en/ga/70/resolutions.shtml

UN World Summit on Sustainable Development, New York. (2015). Retrieved fromhttps://sustainabledevelopment.un.org/post2015/summit

World Bank.(2017a). data.worldbank.org/indicator/EG.USE.COMM.GD.PP.KD

World Bank. (2017b). data.worldbank.org/indicator/NY.GDP.PCAP.CD

\section{Copyrights}

Copyright for this articleis retained by the author(s), with first publication rights granted to the journal.

This is an open-access article distributed under the terms and conditions of the CreativeCommons Attribution license (http://creativecommons.org/licenses/by/4.0/). 